\title{
Paenibacillus phyllosphaerae sp. nov., a xylanolytic bacterium isolated from the phyllosphere of Phoenix dactylifera
}

\author{
Raúl Rivas, Pedro F. Mateos, Eustoquio Martínez-Molina \\ and Encarna Velázquez
}

Correspondence

Raúl Rivas

raul@www.edu-micro.usal.es Departamento de Microbiología y Genética, Edificio Departamental, Campus Miguel de
Unamuno, Universidad de Salamanca, 37007 Salamanca, Spain

\begin{abstract}
A bacterial strain, designated PALXILO4 ${ }^{\top}$, was isolated from the phyllosphere of Phoenix dactylifera. Phylogenetic analysis placed the isolate within the genus Paenibacillus with the closest relatives being Paenibacillus curdlanolyticus and Paenibacillus kobensis. DNA-DNA hybridization measurements showed low DNA relatedness (15-20\%) between the isolate and its closest relatives. Cells were Gram-variable, facultatively anaerobic, motile, sporulating rods. Catalase and oxidase were produced by the organism. Cellulose, starch, aesculin and xylan were hydrolysed. Growth was supported by many carbohydrates as the carbon source. MK-7 was the predominant menaquinone and anteiso- $C_{15: 0}$ the major fatty acid. The $G+C$ content of the DNA was $50 \cdot 7$ mol\%. Phylogenetic, DNA-DNA relatedness and phenotypic analyses indicated that strain PALXIL04 ${ }^{\top}$ represents a novel species of the genus Paenibacillus, for which the name Paenibacillus phyllosphaerae sp. nov. is proposed. The type strain is PALXIL04 ${ }^{\top}$ $\left(=\right.$ LMG $_{22192^{\top}}=$ CECT $\left.5862^{\top}\right)$.
\end{abstract}

Xylan is a heterogeneous polymer composed of $(1,4)$ linked $\beta$-D-xylosyl residues. It is the major hemicellulose component in plant cell walls and is the most abundant polysaccharide after cellulose. Several bacterial and fungal species produce the full complement of enzymes necessary to utilize xylan as a carbon source (Uffen, 1997). Some of these bacterial species belong to the genus Paenibacillus described by Ash et al. (1994). Some members of the genus Paenibacillus excrete a diverse range of extracellular polysaccharide-hydrolysing enzymes, including xylanases (Zamost et al., 1991; Morales et al., 1995; Hespell, 1996; Aÿ et al., 1998; Nielsen \& Sorensen, 1997; Lee et al., 2000; Velázquez et al., 2004).

Here we describe the isolation and classification of a novel xylan-degrading bacterium.

The bacterial strain examined was isolated from a leaf of the palm tree Phoenix dactylifera. The sample was collected aseptically, and $1 \mathrm{~g}$ was chopped, placed in $9 \mathrm{ml}$ sterile water and stirred for $60 \mathrm{~min}$. Aqueous portions $(100 \mu \mathrm{l}$ of the

Published online ahead of print on 18 October 2004 as DOI 10.1099/ ijs.0.63323-0.

The GenBank/EMBL/DDBJ accession number for the 16S rRNA gene sequence of strain PALXIL04 ${ }^{\top}$ is AY598818.

An expanded neighbour-joining tree based on the 16S rRNA gene sequence of strain PALXILO4 ${ }^{\top}$ and representative Paenibacillus strains is available as supplementary material in IJSEM Online. mixture) were spread on XED medium $(0 \cdot 7 \%$ xylan, $0 \cdot 3 \%$ yeast extract, $2 \cdot 5 \%$ agar) in triplicate and incubated at $28^{\circ} \mathrm{C}$. A bacterial strain, designated PALXIL04 ${ }^{\mathrm{T}}$, was isolated after 7 days incubation and a pure culture was maintained in a glycerol suspension $\left(25 \%\right.$, v/v) at $-80{ }^{\circ} \mathrm{C}$.

Strain PALXIL04 ${ }^{\mathrm{T}}$ was grown in YED medium $(0 \cdot 5 \%$ yeast extract, $0.7 \%$ glucose, $1.5 \%$ agar) for $48 \mathrm{~h}$ to check for motility by using phase-contrast microscopy. Gram staining was carried out by using the procedure described by Doetsch (1981). Cells were gently suspended in sterile water, stained with $0 \cdot 2 \%$ uranyl acetate and examined at $80 \mathrm{kV}$ with a Zeiss EM 209 transmission electron microscope (Peix et al., 2003).

Strain PALXIL04 ${ }^{\mathrm{T}}$ was cultivated in TSB (Becton Dickinson) for $24 \mathrm{~h}$ at $28{ }^{\circ} \mathrm{C}$ in a rotary shaker (90 r.p.m.) for menaquinone analyses using freeze-dried cells. The same medium but amended with $15 \mathrm{~g}$ agar $1^{-1}$ was used to cultivate the strain for examination of its fatty acid composition. Menaquinone and cellular fatty acids were analysed as described by Zimmermann et al. (1998).

Physiological and biochemical tests were determined using API 20NE, API 20E and API 50CH strips (bioMérieux) according to the manufacturer's instructions. Amylase, caseinase, catalase, cellulase and oxidase were analysed as described by Rivas et al. (2003). Growth was determined at temperatures of $4-45^{\circ} \mathrm{C}$ in YED medium. 


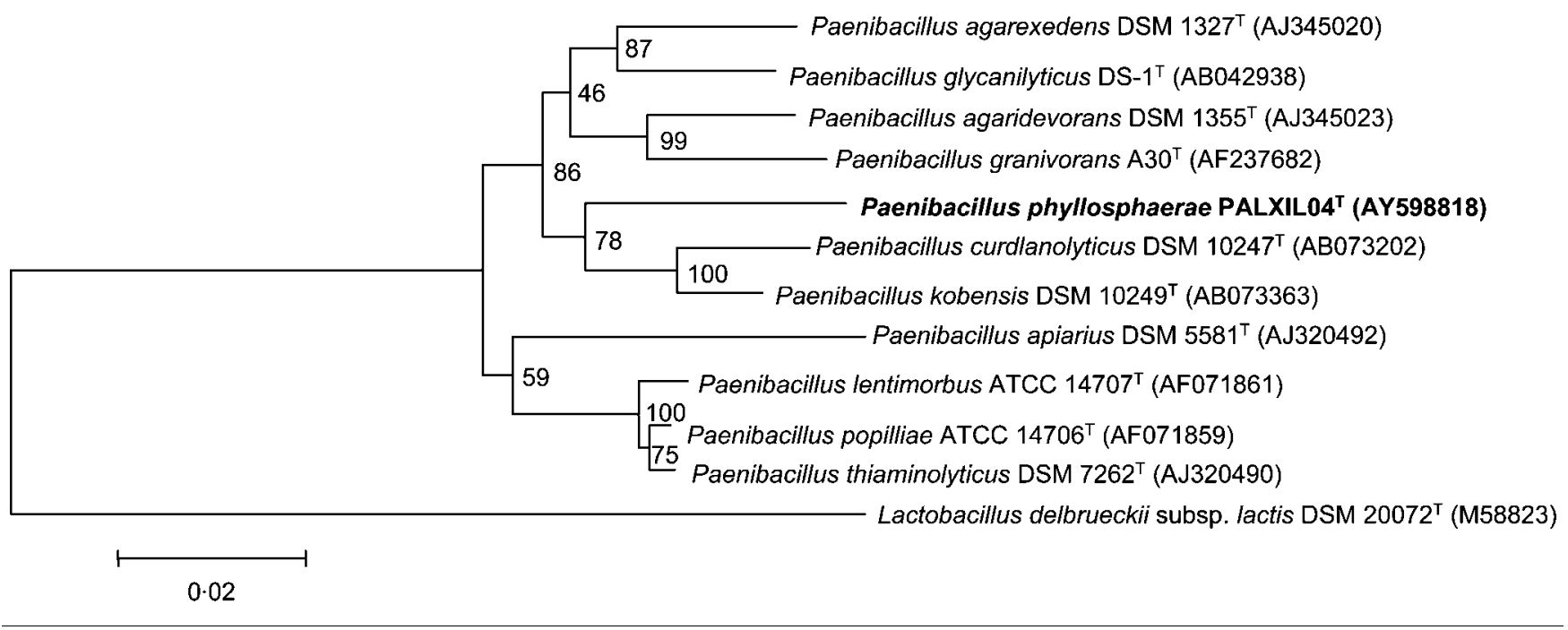

Fig. 1. Comparative analysis of the 16S rRNA gene sequence of Paenibacillus phyllosphaerae PALXILO4 ${ }^{\top}$ and those of representative strains from GenBank using the neighbour-joining method. The significance of each branch is indicated by a bootstrap value calculated for 1000 subsets. Bar, 2 nt substitutions per 100 nt.

DNA for base composition analysis was prepared according to the method of Chun \& Goodfellow (1995). The G+C content of the DNA was determined using the thermal denaturation method of Mandel \& Marmur (1968).

DNA-DNA hybridization was carried out as described by De Ley et al. (1970) with the modifications described by Huss et al. (1983) and Escara \& Hutton (1980). DNA was isolated as described by Cashion et al. (1977).

For 16S rRNA gene sequencing, DNA extraction was carried out as described by Rivas et al. (2001). Amplification and sequencing of the $16 \mathrm{~S}$ rRNA gene were performed according to the method described by Rivas et al. (2003). An almostcomplete 16S rRNA gene sequence was obtained and compared with those deposited in public databases. Sequences were aligned using CLUSTAL X software (Thompson et al., 1997). Evolutionary distances were calculated according to Kimura's two-parameter method (Kimura, 1980). Phylogenetic trees were inferred using the neighbour-joining method (Saitou \& Nei, 1987). Bootstrap analysis was based on 1000 resamplings. The MEGA2 package (Kumar et al., 2001) was used for all analyses.

A comparison of the 16S rRNA gene sequence of strain PALXIL04 $^{\mathrm{T}}$ and sequences held in GenBank indicated that the organism is phylogenetically related to members of the genus Paenibacillus. Fig. 1 shows the phylogenetic tree obtained with the neighbour-joining method (an expanded tree is available as Supplementary Fig. A in IJSEM Online). The closest related species are Paenibacillus kobensis DSM $10249^{\mathrm{T}}$ (95.7 \% similarity) and Paenibacillus curdlanolyticus DSM $10247^{\mathrm{T}}(95 \cdot 0 \%)$.

Details of characteristics that differentiate strain PALXIL04 ${ }^{\mathrm{T}}$ and phylogenetically related species are given in Table 1.
Other characteristics determined are given under the species description below.

Unsaturated menaquinone with seven isoprene units (MK-7) was the predominant isoprenoid quinone found in strain PALXIL04 ${ }^{\mathrm{T}}$. The major cellular fatty acid of strain PALXIL04 ${ }^{\mathrm{T}}$, Paenibacillus curdlanolyticus and Paenibacillus kobensis was anteiso- $\mathrm{C}_{15: 0}$ (Table 2 ), which is the predominant cellular fatty acid found in all recognized members of the genus Paenibacillus (Shida et al., 1997). The fatty acid profile of PALXIL04 ${ }^{\mathrm{T}}$ was similar to those of the type strains of Paenibacillus curdlanolyticus and Paenibacillus kobensis, but differed in the proportions of some fatty acids (Table 2). The main differences were the amounts of $\mathrm{C}_{16: 0}, \mathrm{C}_{17: 0}$ and iso- $\mathrm{C}_{17: 0}$ in the novel isolate compared to Paenibacillus curdlanolyticus and those of anteiso- $\mathrm{C}_{15: 0}$ and anteiso- $\mathrm{C}_{17: 0}$ compared to Paenibacillus kobensis.

DNA-DNA relatedness values for strain PALXIL04 ${ }^{\mathrm{T}}$ against Paenibacillus curdlanolyticus DSM $10247^{\mathrm{T}}$ and Paenibacillus kobensis DSM $10249^{\mathrm{T}}$ were 15 and $20 \%$, respectively, suggesting that the novel isolate was not closely related to species with validly published names according to current species concepts. The results confirm that strains with less than $97 \% 16$ S rRNA gene sequence similarity have DNADNA relatedness values lower than $70 \%$ (Stackebrandt \& Goebel, 1994).

The DNA G+C content of strain PALXIL04 ${ }^{\mathrm{T}}$ was $50.7 \mathrm{~mol} \%$. This value was similar to that obtained for Paenibacillus curdlanolyticus and Paenibacillus kobensis (Shida et al., 1997).

On the basis of phylogenetic, chemotaxonomic and phenotypic data, we propose that strain PALXIL04 ${ }^{\mathrm{T}}$ should be 
Table 1. Characteristics that differentiate Paenibacillus phyllosphaerae sp. nov. from phylogenetically related Paenibacillus species

Species: 1, P. phyllosphaerae; 2, P. curdlanolyticus; 3, P. kobensis. Data are from Kanzawa et al. (1995), Shida et al. (1997), Dasman et al. (2002) and this study. +, Positive; -, negative; w, weak.

\begin{tabular}{|lccc|}
\hline Test & $\mathbf{1}$ & $\mathbf{2}$ & $\mathbf{3}$ \\
\hline Anaerobic growth & + & - & - \\
Oxidase & + & - & - \\
Urease & - & + & + \\
Degradation of: & & & \\
$\quad$ Carboxymethyl cellulose & + & - & - \\
Utilization of: & & & \\
Glycerol & + & + & - \\
Methyl $\beta$-D-xyloside & - & + & + \\
D-Fructose & + & + & - \\
D-Mannose & $\mathrm{W}$ & - & - \\
Rhamnose & $\mathrm{W}$ & - & - \\
Mannitol & + & - & - \\
Methyl $\alpha$-D-mannoside & - & + & - \\
Methyl $\alpha$-D-glucoside & - & + & + \\
N-Acetylglucosamine & - & + & + \\
Arbutin & + & + & - \\
Salicin & + & + & - \\
Melezitose & - & + & + \\
D-Turanose & $\mathrm{W}$ & + & - \\
Gluconate & + & - & - \\
2-Ketogluconate & + & - & - \\
& & & \\
\hline
\end{tabular}

classified as a novel species, with the name Paenibacillus phyllosphaerae sp. nov.

\section{Description of Paenibacillus phyllosphaerae sp. nov.}

Paenibacillus phyllosphaerae (phyl.lo.sphae'rae. Gr. neut. n. phyllon leaf; L. fem. n. sphaera ball, sphere; N.L. gen. fem. n. phyllosphaerae of the phyllosphere).

Spore-forming rods, $0 \cdot 9-1 \cdot 6 \mu \mathrm{m}$ wide, $3 \cdot 3-4 \cdot 2 \mu \mathrm{m}$ long. Gram-variable. Motile by means of peritrichous flagella. Ellipsoidal spores are formed in swollen sporangia and they are in subterminal position in cells. Aerobic or facultatively anaerobic, chemo-organotrophic and xylanolytic bacterium. Colonies on YED medium are circular, flat, whitishcream, opaque and usually $1-3 \mathrm{~mm}$ in diameter within $48 \mathrm{~h}$ at $28^{\circ} \mathrm{C}$. Growth occurs at $10-37^{\circ} \mathrm{C}$ (optimal growth occurs at $28^{\circ} \mathrm{C}$ ) and optimal $\mathrm{pH}$ for growth is 7. Oxidaseand catalase-positive. The $\mathrm{pH}$ in Voges-Proskauer broth is $5 \cdot 3$. Could not grow in the presence of $5 \% \mathrm{NaCl}$. The major quinone is MK-7. The main fatty acid is anteiso$\mathrm{C}_{15: 0}$. Gas is not produced from D-glucose. D-Glucose, glycerol, L-arabinose, D-xylose, galactose, D-fructose, mannitol, amygdalin, arbutin, aesculin, salicin, cellobiose, maltose, lactose, melibiose, sucrose, trehalose, D-raffinose, starch, glycogen, $\beta$-gentobiose, gluconate, 2-ketogluconate,
Table 2. Cellular fatty acid composition of Paenibacillus phyllosphaerae sp. nov. and phylogenetically related species of the genus Paenibacillus

Species: 1, P. phyllosphaerae; 2, P. curdlanolyticus; 3, P. kobensis. Data are from Dasman et al. (2002) and this study. ND, Not detected.

\begin{tabular}{|lccr|}
\hline Fatty acid & $\mathbf{1}$ & $\mathbf{2}$ & $\mathbf{3}$ \\
\hline Saturated & & & \\
Straight-chain: & & & \\
$\quad \mathrm{C}_{14: 0}$ & $1 \cdot 8$ & $0 \cdot 8$ & $1 \cdot 2$ \\
$\mathrm{C}_{15: 0}$ & $\mathrm{ND}$ & $0 \cdot 4$ & $0 \cdot 9$ \\
$\mathrm{C}_{16: 0}$ & $11 \cdot 8$ & $0 \cdot 6$ & $16 \cdot 1$ \\
$\mathrm{C}_{17: 0}$ & $0 \cdot 6$ & $9 \cdot 9$ & $0 \cdot 2$ \\
iso-Branched: & & & \\
$\mathrm{C}_{14: 0}$ & $2 \cdot 2$ & $1 \cdot 8$ & $2 \cdot 3$ \\
$\mathrm{C}_{15: 0}$ & $9 \cdot 9$ & $5 \cdot 4$ & $6 \cdot 1$ \\
$\mathrm{C}_{16: 0}$ & $11 \cdot 1$ & $15 \cdot 4$ & $14 \cdot 5$ \\
$\mathrm{C}_{17: 0}$ & $3 \cdot 3$ & $16 \cdot 4$ & $5 \cdot 2$ \\
anteiso-Branched: & & & \\
$\mathrm{C}_{15: 0}$ & $48 \cdot 6$ & $44 \cdot 6$ & $38 \cdot 5$ \\
$\mathrm{C}_{17: 0}$ & $6 \cdot 4$ & $4 \cdot 7$ & $14 \cdot 0$ \\
Unsaturated & & & \\
$\mathrm{C}_{16: 1} \omega 7 c$ & $1 \cdot 9$ & $\mathrm{ND}$ & $\mathrm{ND}$ \\
$\mathrm{C}_{16: 1} \omega 11 c$ & $1 \cdot 4$ & $\mathrm{ND}$ & $\mathrm{ND}$ \\
\hline
\end{tabular}

xylan, carboxymethyl cellulose and gentiobiose are utilized as carbon sources. Assimilation of D-mannose, rhamnose and D-turanose is weakly positive. In contrast, erythritol, Darabinose, ribose, L-xylose, adonitol, methyl $\beta$-xyloside, Lsorbose, dulcitol, inositol, sorbitol, methyl $\alpha$-D-mannoside, methyl $\alpha$-D-glucoside, $N$-acetylglucosamine, inulin, melezitose, xylitol, D-lyxose, D-tagatose, D-fucose, L-fucose, D-arabitol, L-arabitol, 5-ketogluconate, adipate, caproate, citrate, phenylacetate and malate do not serve as carbon sources for growth. Xylanase, cellulase, amylase and $\beta$ galactosidase are produced actively, but caseinase, arginine dihydrolase, indole, lysine decarboxylase, ornithine decarboxylase, urease, phenylalanine deaminase, tryptophan deaminase, hydrogen sulfide and acetoin (Voges-Proskauer medium) are not produced. Nitrate is reduced to nitrite.

The type strain, PALXIL04 ${ }^{\mathrm{T}}\left(=\mathrm{LMG} 22192^{\mathrm{T}}=\mathrm{CECT}\right.$ $5862^{\mathrm{T}}$ ), was isolated from the phyllosphere of Phoenix dactylifera in Palma de Mallorca (Spain). The DNA G +C content of the type strain is $50 \cdot 7 \mathrm{~mol} \%$.

\section{Acknowledgements}

This work was supported by the CAICYT-DGES and the JCyL (Spanish Government). We are grateful to DSMZ staff for chemotaxonomic analyses.

\section{References}

Ash, C., Priest, F. G. \& Collins, M. D. (1994). Paenibacillus gen. nov. In Validation of the Publication of New Names and New Combinations 
Previously Effectively Published Outside the IJSB, List no. 51. Int J Syst Bacteriol 44, 852-853.

Aÿ, J., Goetz, F., Borriss, R. \& Heinemann, U. (1998). Structure and function of the Bacillus hybrid enzyme GluXyn-1: native-like jellyroll fold preserved after insertion of autonomous globular domain. Proc Natl Acad Sci U S A 95, 6613-6618.

Cashion, P., Holder-Franklin, M. A., McCully, J. \& Franklin, M. (1977). A rapid method for base ratio determination of bacterial DNA. Anal Biochem 81, 461-466.

Chun, J. \& Goodfellow, M. (1995). A phylogenetic analysis of the genus Nocardia with 16S rRNA sequences. Int J Syst Bacteriol 45, 240-245.

Dasman, Kajiyama, S., Kawasaki, H., Yagi, M., Seki, T., Fukusaki, E. \& Kobayashi, A. (2002). Paenibacillus glycanilyticus sp. nov., a novel species that degrades heteropolysaccharide produced by the cyanobacterium Nostoc commune. Int J Syst Evol Microbiol 52, 1669-1674.

De Ley, J., Cattoir, H. \& Reynaerts, A. (1970). The quantitative measurement of DNA hybridization from renaturation rates. Eur J Biochem 12, 133-142.

Doetsch, R. N. (1981). Determinative methods of light microscopy. In Manual of Methods for General Bacteriology, pp. 21-33. Edited by P. Gerdhardt, R. G. E. Murray, R. N. Costilow, E. W. Nester, W. A. Wood, N. R. Krieg \& G. B. Phillips. Washington, DC: American Society for Microbiology.

Escara, J. F. \& Hutton, J. R. (1980). Thermal stability and renaturation of DNA in dimethyl sulfoxide solutions: acceleration of renaturation rate. Biopolymers 19, 1315-1327.

Hespell, R. B. (1996). Fermentation of xylan, corn fiber, or sugars to acetoin and butanediol by Bacillus polymyxa strains. Curr Microbiol 32, 291-296.

Huss, V. A. R., Festl, H. \& Schleifer, K. H. (1983). Studies on the spectrometric determination of DNA hybridization from renaturation rates. Syst Appl Microbiol 4, 184-192.

Kanzawa, Y., Harada, A., Takeuchi, M., Yokota, A. \& Harada, T. (1995). Bacillus curdlanolyticus sp. nov. and Bacillus kobensis sp. nov., which hydrolyze resistant curdlan. Int J Syst Bacteriol 45, 515-521.

Kimura, M. (1980). A simple method for estimating evolutionary rates of base substitutions through comparative studies of nucleotide sequences. J Mol Evol 16, 111-120.

Kumar, S., Tamura, K., Jakobsen, I. B. \& Nei, M. (2001). Molecular Evolutionary Genetics Analysis software. Tempe, AZ: Arizona State University.

Lee, H. J., Shin, D. J., Cho, N. C., Kim, H. O., Shin, S. Y., Im, S. Y., Lee, H. B., Chum, S. B. \& Bai, S. (2000). Cloning, expression and nucleotide sequences of two xylanase genes from Paenibacillus sp. Biotechnol Lett 22, 387-392.

Mandel, M. \& Marmur, J. (1968). Use of ultraviolet absorbance temperature profile for determining the guanine plus cytosine content of DNA. Methods Enzymol 12B, 195-206.
Morales, P., Madarro, A., Flors, A., Sendra, J. M. \& Pérez-González, J. A. (1995). Purification and characterization of a xylanase and an arabinofuranosidase from Bacillus polymyxa. Enzyme Microb Technol 17, 424-429.

Nielsen, P. \& Sorensen, J. (1997). Multi-target and mediumindependent fungal antagonism by hydrolytic enzymes in Paenibacillus polymyxa and Bacillus pumillus strains from barley rhizosphere. FEMS Microbiol Ecol 22, 183-192.

Peix, A., Rivas, R., Mateos, P. F., Martínez-Molina, E., RodríguezBarrueco, C. \& Velázquez, E. (2003). Pseudomonas rhizosphaerae sp. nov., a novel species that actively solubilizes phosphate in vitro. Int J Syst Evol Microbiol 53, 2067-2072.

Rivas, R., Velázquez, E., Valverde, A., Mateos, P. F. \& MartínezMolina, E. (2001). A two primers random amplified polymorphic DNA procedure to obtain polymerase chain reaction fingerprints of bacterial species. Electrophoresis 22, 1086-1089.

Rivas, R., Sánchez, M., Trujillo, M. E., Zurdo-Piñeiro, J. L., Mateos, P. F., Martínez-Molina, E. \& Velázquez, E. (2003). Xylanimonas cellulosilytica gen. nov., sp. nov., a xylanolytic bacterium isolated from a decayed tree (Ulmus nigra). Int J Syst Evol Microbiol 53, 99-103.

Saitou, N. \& Nei, M. (1987). The neighbor-joining method: a new method for reconstructing phylogenetic trees. Mol Biol Evol 4, 406-425.

Shida, O., Takagi, H., Kadowaki, K., Nakamura, L. K. \& Komagata, K. (1997). Emended description of Paenibacillus amylolyticus and description of Paenibacillus illinoisensis sp. nov. and Paenibacillus chibensis. Int J Syst Bacteriol 47, 299-306.

Stackebrandt, E. \& Goebel, B. M. (1994). Taxonomic note: a place for DNA-DNA reassociation and 16S rRNA sequence analysis in the present species definition in bacteriology. Int J Syst Bacteriol 44, 846-849.

Thompson, J. D., Gibson, T. J., Plewniak, F., Jeanmougin, F. \& Higgins, D. G. (1997). The ClUSTAL $X$ windows interface: flexible strategies for multiple sequence alignment aided by quality analysis tools. Nucleic Acids Res 25, 4876-4882.

Uffen, R. L. (1997). Xylan degradation, a glimpse at microbial diversity. J Ind Microbiol Biotechnol 19, 1-6.

Velázquez, E., de Miguel, T., Poza, M., Rivas, R., Rosselló-Mora, R. \& Villa, T. G. (2004). Paenibacillus favisporus sp. nov., a xylanolytic bacterium isolated from cow faeces. Int J Syst Evol Microbiol 54, 59-64.

Zamost, B. L., Nielsen, H. K. \& Starnes, R. L. (1991). Thermostable enzymes for industrial applications. J Ind Microbiol 8, 71-82.

Zimmermann, O., Spröer, C., Kroppenstedt, R. M., Fuchs, E., Köchel, H. G. \& Funke, G. (1998). Corynebacterium thomssenii sp. nov., a Corynebacterium with $N$-acetyl- $\beta$-glucosaminidase activity from human clinical specimens. Int $J$ Syst Bacteriol 48, 489-494. 